\title{
THE PERPLEXING DU PONT CASE: ADDITIONAL CONFUSION IN THE LAW OF MERGERS

\author{
Henry G. Mannet
}

Probably no Supreme Court antitrust case of recent years has taken such a dramatically unexpected turn as United States v. E. I. $d u$ Pont de Nemours \& Co., ${ }^{1}$ and rarely have the bar and writers on a topic been taken so completely by surprise. ${ }^{2}$ It is important, therefore, to understand just what the opinion means and why it represents such a radical departure. This Article will review the decision and its background and then, with considerably less comfort, attempt to define the present status of the Sherman and Clayton Acts in relation to the contemporary merger movement.

Du Pont first made purchases of General Motors stock in $1917^{3}$ and by the time its purchasing program was completed in 1919, its holdings represented twenty-three per cent of General Motors' outstanding stock and an investment of forty-nine million dollars. ${ }^{4}$ Through the ensuing years $\mathrm{d} \mathfrak{u}$ Pont furnished a large percentage of General Motors' requirements for automobile finishes and fabrics. In 1949 the Government brought suit against both companies, ${ }^{5}$ alleging these facts, and charging that the acquisition, a form of vertical integration, resulted in violations of sections 1 and 2 of the Sherman Act

† Visiting Assistant Professor of Law, University of Wisconsin. J.D., 1952. University of Chicago; LL.M., 1953, Yale University.

1. 353 U.S. 586 (1957).

2. See for example, Report of the Atrorney Gentral's National Committee To Study THE ANTITRUst Laws 116 (1955) (hereinafter cited as REPORT). For two who may not have been surprised see Rostow, Over-All Size in How To Coxply Witr THe Antitrust Laws 311, 314 (Van Cise and Dunn eds. 1954) and Levi, Mergers in CONFERENCE ON THE ANTITRUST LAWS AND THE ATTORNEY GENERAL'S COMMITTEE REPORT 73 (Rahl and Zaiding eds. 1955). See also Director \& Levi, Laze and the Future: Trade Regulation, 51 Nw. U.L. Rev. 281, 289 (1956).

3. 353 U.S. at 601.

4. Id. at 602 .

5. United States v. E. I. du Pont de Nemours \& Co., 126 F. Supp. 235 (N.D. III. 1954). The defendants were E. I. du Pont de Nemours \& Company, General Motors Corporation, United States Rubber Company, various individuals and two corporate holders of large amounts of du Pont stock. Christiana Securities Company and Delaware Realty \& Investment Corporation. The appeal, however, only involved du Pont, General Motors and the two holding companies. 
and section 7 of the Clayton Act, as it existed before the 1950 amendment. ${ }^{6}$

Most of the arguments in the district court centered on the Sherman Act, and in awarding the defendants a complete victory, the district court's only reference to the Clayton Act was the following:

"It may be that a violation of the Clayton Act can be made out in the absence of an actual restraint of trade where it is established that there is a reasonable probability that a condemned restraint will result from an acquisition of stock. The acquisition challenged by the Government-du Pont's investment in General Motors-took place over thirty years ago. In those many intervening years the record discloses that no restraint of trade has resulted. Accordingly, the Court is of the opinion that there is not, nor has there been, any basis for a finding that there is or has been any reasonable probability of such a restraint within the meaning of the Clayton Act." 7

\section{The Supreme Court's Opinion}

On direct appeal to the Supreme Court, the district court decision was reversed. Justice Brennan, speaking for the Court, ${ }^{8}$ chose to disregard completely the Government's Sherman Act theory and to rest the decision entirely on the Clayton Act dismissal below. ${ }^{\circ}$ Opinion and thirty-five years of agency inactivity ${ }^{10}$ were not enough to per-

6. In 1950 the first paragraph of $\$ 7$ of the Clayton Act was amended. Deletions are indicated by a line through the deleted words and additions are in italics:

"No corporation engaged in commerce shall acquire, directly or indirectly, the whole or any part of the stock or other share capital and no corporation subject to the jurisdiction of the Federal Trade Commission shall acquire the whole or any part of the assets of another corporation engaged also in commerce, where in any line of commerce in any section of the contntry, the effect of such acquisition may be substantially to substantinlily lessen competition between the corporation whoce stocle is of acquired end the corporation making the acquicition, or to restrain stuch commerce in any section or sommunity, or to tend to create a monopoly of any line of commerce."

38 STAT. 731 (1914), as amended, 15 U.S.C. $\$ 18$ (1952).

7. United States v. E. I. du Pont de Nemours \& Co., 126 F. Supp. 235, 335 (N.D. I11. 1954). For the lower court's notions about the Sherman Act phase of the case, see for example the statements of conclusion. Id. at 254, 276, 282, 296, 301 and 335.

8. Justice Brennan was joined by Justices Black, Douglas and Warren. Justice Burton wrote a vigorous dissenting opinion in which he was joined by Justice Frankfurter. Justices Clark, Harlan and Whittaker took no part in the consideration or decision of the case. Thus, only four members of the present Court are on record as favoring the $d_{\imath \iota}$ Pont decision.

9. See discussion beginning at p. 398 infra for a possible explanation of the Court's motives in this regard.

10. The Federal Trade Commission believed this. FTC, REPORT on Corporatr Mergers and Acovisirrons 154, 168 (1955). Many writers believed it. See for example McLaren, Related Problems of "Requirements" Contracts and Acquisitions in Vertical Integration Under the Antitrust Laws, 45 InL. L. REv. 141 (1950). Some members of Congress believed it. H.R. REP. No. 1191, 81 st Cong., 1st Sess. 8 (1949). 
suade the Court ${ }^{11}$ that the old, unamended section 7 was intended merely to apply to horizontal acquisitions and mergers and not to vertical ones. ${ }^{12}$

The relevant paragraph of the section, the first, describes three separate anticompetitive tendencies of stock acquisitions which will make an acquisition illegal. ${ }^{13}$ The Government had proceeded only under the third alternative ${ }^{14}$ which provides that the acquisition is illegal if its effect is to "tend to create a monopoly" of any line of commerce. ${ }^{15}$ The Court found nothing in the words of the section or its history indicating that this did not include any acquisition of shares which had the expressed anticompetitive effect. Although General Motors and du Pont were not competitors, a violation "occurred if.

11. The Court skirted the problem of the impact of administrative interpretations raised, for instance, by FTC v. Bunte Bros., Inc., 312 U.S. 349 (1941), by saying that the Court "has the duty to reconcile administrative interpretations with the broad antitrust policies laid down by Congress. . . . The failure of the Commission to act is not a binding administrative interpretation that Congress did not intend vertical acquisitions to come withn the purview of the Act. .." 353 U.S. at 590 .

12. The dissenting Justices took issue with this as with almost every other point made by the majority opinion. Perhaps Justice Burton's strongest argument in this connection is his conclusion that "intercorporate relationships between buyers and sellers which resulted in noncompetitive preferences were intended to be dealt with exclusively by the provision forbidding interlocking directorates ( $\$ 8$ of the Clayton Act), if not covered by the specific prohibitions of certain price discriminations $(\$ 2)$, and of certain exclusive selling or leasing contracts $(\S 3) . " 353$ U.S. at 615 ; and see id. at 612 n. 4 .

13. The first of these is a substantial lessening of competition between the company acquiring the stock and the company whose stock is acquired. This provision is applicable to horizontal acquisitions, those involving companies engaged in the same type business. If the parties do not sell in the same geographic market, however, the acquisition would have no more effect on competition than if the products were different. This point is made in Transamerica Corp. v. Board of Governors, 206 F.2d 163 (3d Cir. 1953). There, however, instead of a merger of companies in the same type business, companies in the same type business were acquired by one holding company. The court found that the acquired companies, local banks, competed only in their local geographic area. Technically speaking, if the merged companies do not compete in the same market, for whatever reason, then there has been no horizontal merger but rather a conglomerate or vertical merger. The vertical merger involves two or more companies in different levels or stages of production of the final product or service. Conglomerate mergers would presumably include those in which the only relationship was one of technological or marketing economies or those in which there was no relationship other than desire for diversification.

The next alternative is restraining "such commerce in any section or community." The "such commerce" found in the second alternative test presumably refers back to the only other use of the word "commerce" in the section. The word occurs in the phrase "engaged in commerce" modifying, first, the corporation acquiring the stock and, second, the corporation whose stock is acquired. Since these two companies are not necessarily engaged in the same commerce, presumably a restraint of either would be sufficient. Thus more than merely horizontal acquisitions could be comprehended within the second test, as also by the third, under which the Court in du Pont proceeded. On the other hand, the commerce referred to in this second test is that in "any section or community," presumably a geographical demarcation. If the purpose of this test is only to make that demarcation, then it is arguable that the "such commerce" refers to the "competition" of the immediately preceding clause, and the second test would be limited to horizontal acquisitions, along with the first.

14. The Government may not have been too serious about the Clayton Act aspects of the case, since, as the dissent tells us, only a few minutes of the oral argument and. the closing pages of the brief were devoted to it. 353 U.S. at 609.

15. See text of the act at note 6 supra. 
as a result of the acquisition, there was at the time of suit a reasonable likelihood of monopoly of any line of commerce." 16

In determining whether the acquisition involved this "reasonable likelihood," the market in which the affected competition appeared had to be delineated. The appellees had argued that the relevant market was the total national market for industrial finishes and fabrics, ${ }^{17}$ and since General Motors' purchases of these products constituted merely 3.5 per cent and 1.6 per cent of all sales of industrial finishes and fabrics respectively, there was no tendency to monopoly since the percentages were almost negligible.

But the Court proceeded to an entirely different analysis and indicated that the relevant market test of Standard Oil Co. v. United States ${ }^{18}$ furnished an appropriate approach to the same issue in the instant case. ${ }^{19}$ Standard Stations arose under section 3 of the Clayton Act, prohibiting certain tying arrangements, and involved Standard's use of requirements contracts with its dealers in petroleum products and automobile accessories. The Court there held that the total national market was not in issue, but only that "within the area of effective competition," a seven-state marketing area.

But the "area of effective competition" can be delineated, the Court indicates in $d u$ Pont, in terms of the product as well as the physical area in which it is sold. ${ }^{20}$ The Court found that the fabrics and finishes used in the automotive industry have sufficient peculiar characteristics and uses to constitute them lines of commerce within

16. 353 U.S. at 592. The Court cites Transamerica Corp. v. Board of Governors, 206 F.2d 163, 169 (3d Cir. 1953), defining a monopoly as involving the power to exclude competition when the monopolist desires to do so. The case also indicates that monopoly is a broader term than lessening of competition and necessarily includes the latter. From this it might be deduced that Justice Brennan's analysis will also apply to the other two tests under $\$ 7$.

17. Tetraethyl lead, freon refrigerant and miscellaneous other products were mentioned in the district court opinion, but the Supreme Court dealt only with finishes and fabrics. The Court does not expressly state why it chose these items, or whether it might just as well have chosen others, and the only thing that can be concluded with certainty is that the Court did not think it necessary to view all the relationships between the two companies in order to find a violation of $\S 7$.

18. 337 U.S. 293, 299 n.5 (1949).

19. That this test was used will apparently come as a surprise to many writers. See for example, FTC, REPORT ON CORPORATE MERGERS AND ACQUISITIONS 163 (1955) ; Chadwell, Legal Tests for Violation of Section 2 of the Sherman Act and Section 7 of the Clayton Act in Light of the Cellophane Opinion, 2 ANTrTrust BuLL. 449,461 (1957). Not only did the Court use the Standard Stations relevant market test, but it also used the test of so-called "quantitative substantiality" presented there. See pp. 394-98, 401-06 infra. In the Standard Stations case the requisite effect on fiftyeight million dollars worth of business or $6.7 \%$ of the market was substantial enough to constitute a violation of $\S 3$ when this much business was affected by tying arrangements or exclusive dealerships.

20. Standard Stations used this phrase solely with reference to the geographical area, and the same was true of its use in Transamerica Corp. v. Board of Governors, 206 F.2d 163, 169 (3d Cir. 1953). 
the meaning of the Clayton Act." Thus, "the bounds of the relevant market for the purposes of this case are not coextensive with the total [national] market for finishes and fabrics, but are coextensive with the automobile industry." 22 The Court added that it is undisputed that this market is substantial and proceeded to offer a veritable potpourri of statistics ${ }^{23}$ to show that du Pont had a substantial share of that market. ${ }^{24}$

Having concluded then that there was a distinguishable line of commerce affected, that there was an identifiable relevant market for that line, that the market in which the proscribed effect might obtain was substantial and that the defendant du Pont had a substantial share of that market, the Court was left with two questions: first, could it be shown that the acquisition may tend to create a monopoly; and, second, assuming that it did, must the tendency be shown to have existed at the time of acquisition or might it develop at any time after the initial acquisition of the stock.

Directing itself to the second question first, the Court pointed to the legislative history of the section as indicating that it was intended to arrest the growth of monopolies "in their incipiency and before consummation." 25 "Incipiency" in this context was held to refer to any time at which the acquisition threatened to ripen into the prohibited effect, not merely the time of acquisition. Thus, the holding or use of the stock, not merely its acquisition, may pose the threat of the anti-

\section{353 U.S. at 593-94.}

22. Id. at 594-95. The dissent here, as on other points, disapproved of the Court's even deigning to answer this question since it was considered "an essentially factual question not passed on by the District Court, and not thoroughly briefed or argued by the parties." Id. at 649 n.30. Nonetheless, on the basis of the facts appearing in the record the minority denied that the finishes and fabrics used in the manufacture of automobiles have peculiar characteristics differentiating them from the finishes and fabrics used in other industries. Id. at 650 . A seconding of the minority's position may be found in Adelman, The du Pont-General Motors Division, 43 VA. L. REv. 873 (1957). The minority pointed out, for instance, that in $1948 \mathrm{du}$ Pont's gross sales to purchasers other than General Motors of the "same kinds of finishes" bought by General Motors amounted to about 97 million dollars; and its sales to General Motors in the same year were 21 million dollars. $I d$. at $651 \mathrm{n} .31$. (Emphasis added.)

23. It discusses the size of General Motors in sales, assets and net income. And we are told that in 1947, General Motors purchases from du Pont totalled over twenty-six million dollars, of which nearly nineteen million, or $71 \%$, was from the du Pont Finishes Division. Of these purchases, over twelve million, or $65 \%$, were for Duco and Duco thinner. Fabric purchases in 1948 totaled 3.7 million dollars, making General Motors du Pont's largest customer, with du Pont supplying 52.3\% of General Motors' fabrics in 1946 and $38.5 \%$ in 1947. General Motors accounts for one-half of all the automobiles sold in the country, and its requirements for finishes and fabrics must constitute approximately one-half of the relevant market for these materials; and since du Pont supplies quantitatively and percentagewise the largest part of General Motors' requirements, it is concluded that du Pont must have a substantial share of the relevant market. 353 U.S. at 596.

24. The Court indicates that this is the test required by Standard Stations. 353 U.S. at 595.

25. Id. at 597, quoting from S. REP. No. 698, 63d Cong., 2d Sess. 1 (1914). 
competitive effect. "To accomplish the congressional aim, the Government may proceed at any time that an acquisition may be said with reasonable probability to contain a threat that it may lead to a restraint of commerce or tend to create a monopoly of a line of commerce." 26 The Court bolsters this argument by pointing to the fact that even an acquisition "solely for investment," expressly allowed by the section, ${ }^{27}$ may become a violation if the stock is used or there is an attempt to use it to bring about a substantial lessening of competition. And it should be noted that the Court expressly interpreted "may" to refer to a probability and not a mere possibility of restraint.

The Court next turned to the evidence to see whether or not such a probability existed at the time of the instant suit. Clearly refusing to accept certain conclusions of the lower court, ${ }^{28}$ the majority looked to certain pre-acquisition circumstances of the two companies, such as General Motors' industry share and du Pont's share of General Motors' purchases; ${ }^{29}$ the apparent intent at the time of the acquisition; ${ }^{30}$ any pressure applied to the acquired company to take its supplies from the acquiring company; ${ }^{31}$ and the course of dealing betwen the companies,

26. 353 U.S. at 597. The dissent's argument against this position centers on the words of the statute, 353 U.S. at 620 , but the statutory analysis is bolstered by the additional argument that the Court's ruling is somehow unfair to companies which made good faith stock purchases clearly justified and legal at the time of the purchase. "The growth of the acquired corporation, a fortuitous decline in the number of its competitors, or the achievement of control by an accidental diffusion of other stock may result, under this test, in rendering the originally lawful acquisition unlawful $a b$ initio. Strikingly enough, all of these factors are involved in this case." Id. at 623.

27. "This section shall not apply to corporations purchasing such stock solely for investment and not using the same by voting or otherwise to bring about, or in attempting to bring about, the substantial lessening of competition. ..."38 STAt. 731 (1914), as amended, 15 U.S.C. $\$ 18$ (1952).

28. The Court denied that there was any dispute as to the "basic facts." Thus, it held inapplicable rule 52(a) of the Federal Rules of Civil Procedure, that findings of fact shall not be set aside uniess clearly erroneous. 353 U.S. at 598 n.28. But see United States v. Yellow Cab Co., 338 U.S. 338 (1949). Among the errors found in the lower court's opinion was the conclusion that thirty years of non-restraint negated a reasonable probability of restraint at the time of suit.

29. General Motors only manufactured $11 \%$ of the total number of automobiles produced at the time of acquisition, and du Pont was not in a "commanding position" as a General Motors supplier before the acquisition. 353 U.S. at 598.

30. Ibid. du Pont had expanded its facilities tremendously during World War I. It had money to invest and it needed new markets for its war-expanded production. John J. Raskob, then treasurer of the du Pont Company, thought that with the General Motors stock purchase du Pont "would ultimately get all that business." Id. at 600 . He also thought that this would be "a substantial factor." Id. at 602. (Emphasis added by the Court.) It is inconceivable that the use of "substantial" by Raskob hao any relevance for Clayton Act purposes, but the Court seems, by its emphasis, to be drawing some meaning from what appears to be a sheer coincidence. The emphasis is either intended to be a play on words or it is completely meaningless.

31. The Court was impressed by statements that the General Motors Divisions should be "put in a frame of mind necessary for its adoption [du Pont's artificial leather]." 353 U.S. at 603 . Since the Court obviously does not think that all businessmen talk this way, the statement must have been viewed as a kind of veiled threat. Of more convincing nature is the evidence of du Pont's "lines of communication" set up within General Motors to learn of the products being used. This was viewed as a fac- 
with special emphasis on any increase in trade between them after the acquisition. ${ }^{32}$ Also noted was the fact that du Pont representatives sat on General Motors' Board of Directors: ${ }^{33}$ the Court points out in a footnote that the importance of a twenty-three per cent bloc of stock was increased when ninety-two per cent of the remaining shareholders held less than one hundred shares each. ${ }^{34}$ The Court took some cognizance of the fact that in later years competitors obtained an increased percentage of General Motors' business but concluded that this was at least in part due to General Motors' requirement's outstripping du Pont's production. Nonetheless, the facts as found provide the Supreme Court with a very different inference than they did the district court.

"The inference is overwhelming that du Pont's commanding position was promoted by its stock interest and was not gained solely on competitive merit. . . . ${ }^{35}$ [D] uPont purposely employed its stock to pry open the General Motors market to entrench itself as the primary supplier of General Motors' requirements for automotive finishes and fabrics. . ..$^{36}[\mathrm{~T}]$ he fact that all concerned . . . in both companies acted honorably and fairly, each in the honest conviction that his actions were in the best interests of his own company and without any design to overreach anyone, including duPont's competitors, does not defeat the Government's right to relief. It is not requisite to the proof of a violation of $\$ 7$ to show that restraint or monopoly was intended." 37

The Court found that vertical acquisitions were intended to be included within section 7 as a matter of word interpretation and legis-

tor which would have some impact on General Motors purchasing officials. Id. at 603 , as well it might, though General Motors might also have welcomed similar attention from other suppliers.

32. In 1918 Flint Varnish and Chemical Works, previously the principal supplier of paints to General Motors, was brought out by du Pont. 353 U.S. at 603 . As Justice Brennan put it, the president of Flint "saw the handwriting on the wall." Other acquisitions are also mentioned, but they were all prior to 1918. Id. at 600 .

33. Lammot du Pont was for a time the Chairman of the Board.

34. 353 U.S. at 607 n.36. Of course, this does not give all the relevant figures, for it tells nothing about the relative sizes of other large holdings.

35. Id. at 605. This language contrasts markedly with much of that of the district court. See text at note 7 silpra and compare, for instance the following language: "Du Pont, the record shows, has maintained its position as the principal fabric supplier to General Motors through its early leadership in the field and by concentrating upon satisfactorily meeting General Motors' changing requirements as to quality, service and delivery." United States v. E. I. du Pont de Nemours \& Co., 126 F. Supp. 235,301 (N.D. I11. 1954). The dissent in the Supreme Court indicated an agreement with the lower court and a willingness to accept its findings in this regard as findings of fact. 353 U.S. at 628.

36. Id. at 606 .

37. Id. at 607. A lot of the evidence looks like intent evidence, but presumably it is there merely to show that there was a greater probability of the prohibited effect occurring because it was intended. Logically then, it seems that power plus any reasonable likelihood that it would be used, i.e., that it would benefit the defendant, might be sufficient. 
lative history. This assumes that vertical integration can have an anticompetitive effect. Some writers, however, allege as an abstract proposition that vertical acquisitions can never have an anticompetitive effect, $^{38}$ and if their position be accepted, such acquisitions would hardly be within the intended scope of section 7 . Nevertheless, once the Court found that vertical acquisitions, as a definable phenomenon, were included, the next question logically before it was whether this particular one had the proscribed anticompetitive effect. This problem was also avoided, apparently in the belief that Standard Stations, which was heavily relied upon, obviated the need for such inquiry. The Court had there said:

"We are dealing here with a particular form of agreement specified by section 3 and not with different arrangements . . . that may tend to lessen competition. To interpret [section 3] as requiring proof that competition has actually diminished would make its very explicitness a means of conferring immunity upon the practices which it singles out. Congress has authoritatively determined that those practices are detrimental where their effect may be to lessen competition." ${ }^{39}$

And, of course, the practices in Standard Stations (exclusive dealerships) did have that effect, for, as the Court noted, they effectively foreclosed the supplier's competitors from that part of the market. Consequently, the only real inquiry left was the size of the relevant market and the share of the defendant.

The Court, though it never made the point explicitly, clearly believed that an acquisition of a customer has the same economic consequences, or at least the probability of the same economic consequences, as a tying arrangement, ${ }^{40}$ since competitors of the acquiring company

38. See Bork, Vertical Integration and the Sherman Act: The Legal History of an Economic Misconception, 22 U. CHI. L. REv. 157 (1954); Comment, Vertical Forestalling Under the Antitrust Laws, 19 U. CHI. L. Rev. 583 (1952).

39. Standard Oil Co. v. United States, 337 U.S. 293, 311 (1949). This quotation does not appear in the $d u$ Pont decision, but the implication is unmistakable that acquisitions of ctustomer corporations, like tying arrangements, are illegal per se if the requisite quantity of the market is affected. The dissenting opinion, of course, denies that a per se approach to vertical acquisitions is allowable. Perhaps this takes on added emphasis when it is realized that Justice Frankfurter, the author of the per se doctrine in Standard Stations, is dissenting. His shift was not a sudden one. See his dissent in FTC v. Motion Picture Advertising Co., 344 U.S. 392, 401-03 (1953). For a recognition of what was viewed as a "no more per se" approach by the Court, see Report, at 142; Sunderland, Antitrust Developments: $A$ New Era for Competitive Pricing, 41 A.B.A.J. 113, 115 (1955).

40. What these economic consequences may be is never made clear in the cases. Perhaps it is price discrimination. See Bork, supra note 38, at 197; Director \& Levi, supra note 2, at 293; see United States v. United Shoe Mach. Corp., 110 F. Supp. 295,323 (D. Mass. 1953), aff'd per curiam, 347 U.S. 521 (1954), stating that simple foreclosure of a competitor is not basic enough, since that occurs every time a sale takes place. 
are then foreclosed from that much of a relevant market. Since this is an almost necessary result of a total acquisition of stock, then the question arises whether the same conclusion follows if less than all the stock is acquired. The answer is that it does if the stock acquired gives probability of control.

It should be clear, however, that this is not the probability question connoted by the term "incipiency." The reference there is most likely to the probability of certain economic consequences. And certainly that is the thrust of the discussions of incipiency in other cases. ${ }^{41}$ Again, however, it must be noted that to go into this question of economic probability raises the very issues which Justice Frankfurter in Standard Stations declared Congress had foreclosed from the Court's consideration, and it may also be noted that in that case there was no discussion of probability, as presumably there would not have been in $d u$ Pont if the acquisition had been a total one. The incipiency notion appears in section 3 as well as in section 7 , as far as the words of the act are concerned, since both sections use the same "effect . . . may be . . . or tend to. . . ." language. The incipient evil aimed at must be the same in both sections. But no question of probability of control is logically feasible under section 3, although a question about economic probabilities is quite feasible. It would seem then that this is the matter intended to be attacked in each section.

This analysis has serious implications for the Court's appropriate time rule. If the probabilities referred to by the incipiency test of section 7 pertain to certain economic consequences, the probabilities would be just as great at the time of the acquisition as at any time thereafter, ${ }^{42}$ though perhaps not as easily measured. The control could never be stronger nor the ability greater to foreclose or "squeeze" competitors, shift a monopoly from one level to another, undersell competitors, raise the cost of entry into the industry, or do any of the other things which are supposed to make vertically integrated firms undesirable. ${ }^{43}$ And presumably the appropriate, or at least a sufficiently

41. International Shoe Co. v. FTC, 280 U.S. 291 (1930) ; Standard Fashion Co. v. Magrane-Houston Co., 258 U.S. 346 (1922); Transamerica Corp. v. Board of Governors, 206 F.2d 163 (3d Cir. 1953).

42. It should be noted, however, that even in the case of a total acquisition the share of the market held by the company whose stock was acquired may change in percentage, though its absolute amount remains the same. This should not change the analysis, since the increased percentage presumably reflects forces other than those implicit in the acquisition; and there should, it seems, be some causal relationship between the acquisition and the increased probablity of a restraint before the acquisition is found illegal. Query, however, whether the "thrust upon" defense is available in a Clayton Act case.

43. Bork, supra note 38, at 194-201 ; see Markham, Merger Policy Under the New Section 7: A Six Year Appraisal, 43 VA. L. Rev. 489, 497 (1957). 
appropriate time at which the probability of these effects occurring might be investigated is when the acquisition took place.

But, on the other hand, if the probability referred to is the probability that twenty-three per cent of the shares of a company may control, or at least have some determinative influence, then the inquiry is of a different order. It is manifest that situations may change after the acquisition to affect the ability of a bloc of shares to control the company. For example, a fifty per cent bloc of stock held at the time of the twenty-three per cent acquisition might be later sold so that apart from the twenty-three per cent bloc no one held more than one per cent of the shares. ${ }^{44}$ Clearly if probability of control is the incipient evil, it must be open to the Government to inquire into an acquisition at any time.

The difficult case like $d u$ Pont, however, really involves both questions: the probability of economic consequences and the probability of control by less than fifty-one per cent of the shares. A combination of the two approaches would indicate that probability of control should be investigated at the time of suit and that the time of acquisition is the proper moment at which to look for economic consequences. But this makes no sense, for the time chosen to look for probable economic consequences is one at which there may be no economic consequences since there may be no probability of control. On the other hand, to select the later point of time for both considerations, although it might seem to comport with the purposes of the act, was probably not intended since it would result in applying a different rule to total as opposed to partial stock acquisitions. One might conclude that Congress probably thought only in terms of suits being brought at or near the time of acquisition.

But regardless of the approach adopted on the incipiency question. there is still the necessity for defining a relevant market. The statutory use of the words "competition" and "monopoly" implies a market phenomenon and, of course, monopoly is nothing more in this connection than a lack of competition. Competition does not necessarily mean a large number of separate units; for most purposes a definition will suffice which comprehends inability on the part of any unit or combination of units to control price or restrict entry into the industry. The question of relevant market in antitrust law, however, raises a somewhat different question: Is there a market definable not only in the economists' terms but also logically relevant to the complaint at suit? Thus in Standard Stations the Court recognized the existence of a national market for petroleum products but the case was only

44. For the dissent's use of this point, see note 26 supra. 
concerned with the seven-state area within which the defendant operated and competed. For purposes of the suit against Standard, only the competition within that area was relevant at all. Likewise in the $d u$ Pont case it is the market in which the defendant du Pont competes which is crucial and du Pont's share of that market.

For purposes of defining the market, the Court quoted the "area of effective competition" language found in Standard Stations which there dealt with geographic dimensions. ${ }^{45}$ But the Court obviously did not intend to use "area" in that fashion in $d u$ Pont, for it is clear that geographical considerations were meaningless in the case. The phrase "area of effective competition" was used out of context to denote the necessity of describing and delimiting all the appropriate dimensions of a relevant market. If the relevant market had been limited only to industrial finishes and fabrics, du Pont's share of the market would not have been "substantial," since the figures for finishes and fabrics were respectively 3.5 per cent and 1.6 per cent.

But what other dimension or factor could further narrow the market definition? One possibility, and the one selected, is that of product distinction. Thus, unless all manufacturers of industrial finishes and fabrics competed for all the business of industrial users, the Court need look only at the figures for distinguishable items for which business the manufacturers did in fact compete. ${ }^{48}$ This kind of relevant market determination has a respectable history in Clayton Act litigation, since very much the same approach was used in the International Shoe ${ }^{47}$ case, a critical decision in the development of the law under the older section 7. There it was found that shoes designed for country gentlemen did not compete with those designed for city slickers, and presumably each type constituted its own separate market for Clayton Act purposes. Consequently, an acquisition by a company predominantly in the fancy shoe business of the stock of a business in the other field did not violate the Clayton Act. The Court in du Pont looked to the characteristics and uses of automobile finishes and fabrics and found that they were sufficiently peculiar to make them distinct from other finishes and fabrics. Automotive finishes and fabrics constituted a separate "line of commerce."

In order to distinguish the characteristics of one product, which might otherwise seem similar to another, its qualities in terms of what

45. This was true of the Transamerica case as well. See text at notes 76-88 infra.

46. It should perhaps be noted that this is a rather restricted view of competition, since it omits reference to the competitive force exerted by prospective entrants to the particular industry if it becomes attractive enough.

47. International Shoe Co. v. FTC, 280 U.S. 291 (1930); see V. Vivaudou, Inc. v. FTC, 54 F.2d 273 (2d Cir. 1931). See note 77 infra. 
it will and will not do and what it can and cannot be used for would seem pertinent. But the Court offers no evidence along that line at all. Instead it shows that the automobile industry had peculiar needs which had the effect of speeding the development of new lacquers and paints. There is no indication that these new products did not have great usefulness in other industries as well. On the characteristics of fabrics we are merely told that the industry has need for a great variety of colors and finishes so that there can be no standardization of price; but nothing in this statement indicates that the materials were so peculiar that they might not be used in other industries or that sellers to other industries might not be able to sell in the automobile industry. Apparently there was no evidence in the record on the issue at all.

Another possible means of narrowing the relevant market would be in terms of marketing techniques or selling activities. It might just as well have been said, for instance, that a different sales approach must be made to greasy automobile manufacturers than to highly polished furniture makers and that differently trained salesmen were required. Also the techniques of merchandising in one field are very apt to be quite different from the techniques in another, and it would be possible for this reason to distinguish otherwise similar products. But this approach was not suggested.

The Court made another puzzling point, however, by saying that uses as well as characteristics were important in delimiting the relevant market. One might first ask of what relevance is the particular use to which the product is put when the case alleges a tendency to monopoly in the industry in which the seller is supposed to be competing. If the finishes and fabrics are similar and reasonably substitutable, then the particular use made of them by different industries is immaterial to the seller. He wants to have a sale rather than let his competitor have it, but neither of them cares if some of the customers are drinking the stuff.

The fact that the Court may have had particular uses in mind as distinguished from product characteristics, is indicated by the citation of Van Camp \& Sons Co. v. American Can Co. ${ }^{48}$ That case arose under section 2 of the Clayton Act, which forbids price discrimination having the tendencies found also in sections 7 and 3. Section 2, of course, was the forerunner of the present Robinson-Patman Act. Plaintiff in Van Camp alleged that American Can was discriminatorily cutting the price of cans to the Van Camp Packing Co., plaintiff's competitor in the food packing industry. To the contention that "in any

48. 278 U.S. 245 (1929). 
line of commerce" was limited to the line of commerce in which the discriminator was engaged and not another in which the purchasers from the discriminator were engaged, the Court answered that the words "any line" were so clear as to negate that contention. This has generally been thought to mean that the market at any functional level of a total productive process may serve as the relevant one for inquiry as to a tendency to lessen competition, ${ }^{49}$ and the phrase "line of commerce" has been thought to refer to what the economist might call an industry rather than what the drummer calls his "line." To the Court, however, "line of commerce" connoted a distinctive product, and the relevant market was the market for that product. Thus, the relevant market for the $d u$ Pont case was the market for the distinctive products, automotive finishes and fabrics, the lines of commerce involved.

It cannot be denied that the use made of finishes and fabrics by the automobile industry are distinctive uses from those of furniture makers; this may be said if for no other reason than that the two compete in entirely separate product markets. The same might be said about the use of finishes by an automobile manufacturer exporting his total production and another selling his entire output domestically. But, as we have seen, this is a matter of indifference to the manufacturers of finishes and fabrics which are in fact usable in any of the several businesses.

The majority seems to have viewed $\operatorname{Van} \operatorname{Camp}$ in terms of its results-as applying a rule to protect certain "users" of tin cans and guaranteeing them a competitive market in which to buy. It is possible that the Court was thinking not of the foreclosure of du Pont's competitors but rather of the denial to General Motors of the power to make its purchases in a competitive market. Of course, in a situation like this, one cannot exist without the other, but the emphasis, and possible results, ${ }^{50}$ are decidedly different. As we have seen, Justice Brennan indicated that he thought that the possible harm in the arrange-

49. See, e.g., Burns, The Anti-trust Laws and the Regulation of Price Competition, 4 LAW \& CoNTEMP. PROB. 301, 309 (1937).

50. The results would certainly be different if the competition in question were only on the buyers' side and not the sellers'. Suppose for instance that only two companies, one a manufacturer of artists' paints and the other of home dyeing compounds, were the only users of a particular dye manufactured by only one company. An acquisition of the latter company by either of the others might well under the buyers' market analysis suggested by du Pont result in a violation of $\S 7$. The hypothetical suggests the facts of a case cited by Justice Burton in his dissent, Fargo Glass \& Paint Co. v. Globe Am. Corp., 201 F.2d 534 (7th Cir. 1953). That case was a civil suit under $\S 7$ in which the plaintiff complained about the acquisition of the only company manufacturing the type of oven used by plaintiff in assembling kitchen ranges. The oven, however, was not a patented item, and the court found that there were seventy other potential manufacturers of the same item or manufacturers of competitive items so that the competition engaged in by the plaintiff was not restrained in any way. Query whether the case would not be decided differently after $d u$ Pont. Presumably if a patent or some other form of legal monopoly existed at the seller level, the case would be much easier. $C f$. International Salt Co. v. United States, 332 U.S. 392 (1947). 
ment was to du Pont's competitors. Although not specifically mentioned, he may also have seen some possibility of harm to the noncontrolling stockholders of General Motors. ${ }^{51}$

Nonetheless, by defining the relevant market so narrowly, the Court has given just the protection to buyers which was denied them by the relevant market test of the famous Cellophane case ${ }^{52}$ which involved an unsuccessful charge of monopolization by a single firm under section 2 of the Sherman Act. ${ }^{53}$ There the market was broadly defined to include all flexible wraps which might be found to be reasonably substitutable for cellophane. This, of course, had the effect of offering no protection to users of cellophane for whom other products were not effective substitutes. A $d u$ Pont approach would certainly have given a very different result, since in all likelihood the characteristics and uses of cellophane are much more peculiar than those of Duco, vis-à-vis their closest substitutes. A narrow definition of the relevant market, therefore, has the effect of guaranteeing to more individual firms a competitive market in which to buy, at least in cases like Cellophane and du Pont.

\section{The Legal Background of the du Pont Decision}

A full understanding of the opinion requires some inquiry into the previous law with respect to acquisitions and mergers. This includes not only developments under the old and new section 7 of the Clayton Act, but developments under the Sherman Act as well.

\section{Sherman Act}

Perhaps a clue to the direction in which the law would turn can be found in a few sentences in the Report of the Attorney General's National Committee To Study the Antitrust Lazes: ${ }^{54}$

"The application of Sections 1 and 2 of the Sherman Act to cases involving mergers reveals no consistent pattern [citing cases]. We refrain here from detailed analysis and evaluation of this whole line of cases. . . . Third, and more important for all practical

51. This is a pervasive suggestion about the whole notion of vertical integration by partial stock acquisition. Clearly it is not an antitrust problem, but it inevitably comes to mind as one ponders what might be wrong with du Pont's acquiring $23 \%$ of General Motors.

52. 351 U.S. 377 (1956). This opinion was written by Justice Reed and joined in by Justice Burton. It is not surprising, therefore, to find Justice Burton referring to it as presenting the appropriate test for the relevant market in du Pont. 353 U.S. at 649 .

53. If the holding were understood this way, it might have the effect of changing the result in certain private civil suits. Generally, private suits by buyers cut off from supplies have failed "perhaps due to the recognition that Section 3 of the Clayton Act is fundamentally designed to protect the seller's competitors from being foreclosed from the market. ..." RePorr, at 136 n.28. See also Miller Motors, Inc. v. Ford Motor Co., 149 F. Supp. 790, 809 (M.D.N.C. 1957).

54. REPORT, at 115 n.1. 
purposes, the amended Section 7 of the Clayton Act is the primary provision to which the Department of Justice and the Federal Trade Commission will resort to test the legality of mergers. . . " "5s

The Sherman Act law on mergers was indeed somewhat difficult to unscramble, but, as will be shown, the Court may have had more reasons than that for declining a Sherman Act interpretation.

Three cases would seem to be sufficient to assess the Sherman Act background ${ }^{56}$ of the $d u$ Pont case.

United States $v$. Yellow Cab Co. ${ }^{57}$ the first of these cases, gave every indication at the time it was decided of establishing a per se rule of illegality for vertical integration. The facts, incidentally, bear a close resemblance to those of the instant case, for there a cab manufacturing company and its principal stockholder acquired control of four operating cab companies, in one of which a fifteen per cent interest was sufficient for control. The companies were required to purchase cabs only from the parent company. Justice Murphy said that this denied the cab companies the opportunity to purchase in a free, competitive market and violated the Sherman Act.

The case involved a conspiracy charge, but nonetheless, the Government subsequently attempted to work a per se rule out of the wording of the opinion. This was denied in United States $v$. Paramount Pictures, Inc. ${ }^{58}$ which seems to have added an abuse test to the vertical integration rule of $Y$ ellow $C a b$. The case involved predatory practices on the part of integrated companies producing, distributing and exhibiting movies. The abuses included, among other things, a tying arrangement called "block booking," unreasonably long clearance periods between first and second run exhibitions, price fixing and a conspiracy. An attempt to shift monopoly power from one level to another in a vertical set-up also constitutes such an abuse..$^{59}$ Specific intent to monopolize would also serve if no abuses were present. ${ }^{60}$

55. Had the Committee but known that the unamended $\S 7$ had as much force as the new one in stock acquisition cases, the report could have included the old section as another primary provision.

56. This would include more than acquisitions of stock and assets, however, since integration can come about in a variety of other ways, for example, by exclusive dealerships, long term pricing contracts, requirements contracts and tying arrangements.

57. 332 U.S. 218 (1947).

58. 334 U.S. 131 (1948). See also United States v. Griffith, 334 U.S. 100 (1948).

59. See United States v. New York Great A \& P Tea Co., 173 F.2d 79 (7th Cir. 1949) ; United States v. General Motors Corp., 121 F.2d 376 (7th Cir. 1941). For the view that vertical integration is in itself an abuse leading to a violation when coupled with the requisite power, see Levi, $A$ Two Level Anti-Monopoly Law, 47 Nw. U.L. REv. 567, 584 (1952) ; Turner, Antitrist Policy and the Cellophane Case, 70 HARV. L. REv. 281, 306 (1956) (for a similar analysis of the combination cases).

60. A finding of a lack of specific intent to conspire was treated as the only issue in the Supreme Court when the Yelloze Cab case made its second appearance there. 
In United States v. Columbia Steel Co. ${ }^{61}$ the Government again asked for what seemed a per se rule in cases of vertical integration and relied heavily on $Y$ ellow $C a b$, presumably because there was no overt predatory abuse or specific intent to monopolize. ${ }^{62}$ The Court expressly denied that $Y$ ellow $C a b$ stood for per se illegality but said that it merely meant that vertical integration should not be a cover-up for what would otherwise constitute a conspiracy. Instead the Court applied what it considered the abuse rule announced in Paramount. It looked to see if the acquired company comprised a large enough percentage of the relevant market consumption of rolled steel products to restrict unreasonably other suppliers in their ability to market such products. The three per cent which the acquired company represented in the relevant market area did not have that effect. ${ }^{63}$

Possibly the $d u$ Pont facts would constitute a violation of the Sherman Act under Columbia Steel, assuming that the $d u$ Pont relevant market definition were accepted. The percentage of market for automobile finishes affected, something like thirty-four per cent, ${ }^{64}$ must surely have been considered enough to satisfy whatever requirement of substantiality Columbia Steel intended. But other problems would still be present. In the first place, it cannot be said with any degree of certainty that the Court would be willing to treat this as a merger at all. If there had been an express finding that $d u$ Pont did in fact control General Motors, perhaps this would have been no great problem. But the Court made no flat finding of corporate "control." Rather it talked in terms of "potency of the influence" ${ }^{\circ 5}$ leading to a "reasonable probability" ${ }^{86}$ of a tendency towards monopoly. These are Clayton Act, not Sherman Act, propositions.

Nor would the alternative test of specific intent found in Columbia Steel ${ }^{67}$ be of much help. One must take note of Justice Brennan's ex-

The Court did not disagree with the lower court's finding. United States v. Yellow Cab Co., 338 U.S. 338 (1949).

61. 334 U.S. 495 (1948). A fuller treatment of the law and economics of vertical integration may be found in Bork, supra note 38; Comment, Vertical Forestalling Under the Antitrust Lazws, 19 U. CHI. L. REv. 583 (1952). But see Kahn, Standards for Antitrust Policy, 67 HARv. L. REV. 28, 45 (1953); Markham, supra note 43.

62. But see Comment, Vertical Forestalling Under the Antitrust Laws, $19 \mathrm{U}$.

Chr. L. Rev. 583, 591 n.62 (1952).

63. The rule of the du Pont case is almost identical under most non-legal, descriptive verbalizations with that in the $Y$ elloze $C a b$ case. Since this is true, it will be interesting to see if the Clayton Act too will have its Paramount and Columbia Steel developments. See discussion of this point beginning on p. 408 infra.

64. Du Pont supplied 68\% of General Motors' finishes in 1948 and General Motors used one-half the market total. So du Pont supplied approximately $34 \%$ of the market total to General Motors. 353 U.S. at 596.

65. Id. at 607 n.36. See also Hamilton Watch Co. v. Benrus Watch Co., 114 F. Supp. 307, 316-17 (D. Conn.), aff'd, 206 F.2d 738 (2d Cir. 1953).

66. 353 U.S. at 607. The Court is referring to control, not monopoly, as the context makes clear.

67. United States v. Columbia Steel Co., 334 U.S. 495, 523 (1948). 
press remark that the $d u$ Pont case showed no design to overreach anyone. "It is not requisite to the proof of a violation of $\S 7$," he continued, "to show that restraint or monopoly was intended." 68 One might conclude, therefore, that the intent was in fact not present in the case.

\section{Clayton Act}

There is less case material background for the $d u$ Pont case under the Clayton Act than under the Sherman Act. And yet we have an even more accurate notion of the supposed status of the Clayton Act's amended section 7 prior to the $d u$ Pont decision. In only one individual civil suit had an attempt been made to use section 7 in a vertical merger situation, ${ }^{69}$ and the Federal Trade Commission was on record as interpreting the older section to apply only to horizontal mergers. ${ }^{70}$

Since the enforcing agencies had never applied section 7 to vertical acquisitions, the only conclusions about the law prior to $d u$ Pont must be drawn from other kinds of cases construing either section 7 or similar words in another section of the Clayton Act. Much of the history (and surely it is that) of the pre-du Pont approach of the Federal Trade Commission may be found in the Pillsbury Mills case, the Commission's first use of the amended section $7 .^{\mathbf{7 1}}$ At issue was the acquisition by Pillsbury of certain flour mills and baking mix manufacturers in the southeastern part of the United States. The Commission had to decide whether to apply the Standard Stations test of quantitative substantiality or an "all relevant facts" test or still a third, intermediate alternative using something less than "all" the relevant facts.

The Standard Stations test, of course, presumes that the proscribed kind of conduct is bad per se and that if enough of it appears-quantitative substantiality - the statute is violated. The latter two tests referred to in Pillsbury deny the first test's implicit rule of law or per se approach and require an economic analysis of each new set of facts. The standard is whether the industry is acting or performing competitively, but a merger does not necessarily carry any anticompetitive implication.

68. 353 U.S. at 607.

69. Ronald Fabrics Co. v. Verney Brunswick Mills, Inc., CCH Trade, Reg. Rep. (1946-47 Trade Cas.) II 57,514 (S.D.N.Y. 1946). The report is only of the denial of a motion to dismiss on the ground that $\$ 7$ applied only in horizontal acquisitions. The court merely alluded to the tripartite provision as making the complaint sufficient as a matter of law.

70. FTC, Report on Corporate Mergers aNd Acouisitions 154, 168 (1955). However, the discussion beginning on page 154 of the report dealing with the differences between the earlier version of $\S 7$ and the amended $\S 7$ does not even deal with the "tend to monopoly" provision. The omission is a peculiar one.

71. Pillsbury Mills, Inc., F.T.C. Docket 6000 (Dec. 21, 1953). 
The Commission noted that a per se test, while reasonable for tying cases, had no application to the merger situation. As between the "all" and the "something less than all" relevant facts tests, the Commission chose the latter because the other could not be used in time to prevent a substantial lessening of competition. Exactly what this means is still uncertain, since, nearly four years after the case was sent back to the trial examiner, no further report of findings has been made. And the Commission had agreed that the findings already indicated a prima facie case of violation of section 7 .

The Commission felt that the quantity of the relevant market affected by a merger was merely one of the many facts to be considered in determining whether there was a violation of the section. ${ }^{72}$ Conceivably, if the figures were large enough, that finding would be sufficient in itself, ${ }^{73}$ but generally more would be required. ${ }^{74}$ The Commission looked at the pattern of acquisitions in the industry and by Pillsbury in particular and noted a general increase in the major com-

72. Justice Brennan certainly did not make a case-by-case analysis of all the relevant economic factors as was done under the Sherman Act phase of the case by the district court. The position seems clearly taken, moreover, that the Clayton Act does not allow such an approach. The interpretation of words in $\S 3$ of the act was taken as the meaning of the identical words in $\$ 7$. Compare, for instance, these words from Standard Oil Co. v. United States, 337 U.S. 293, 312 (1949) : "It seems hardly likely that, having with one hand set up an express prohibition against a practice thought to be beyond the reach of the Sherman Act, Congress meant, with the other hand, to reestablish the necessity of meeting the same tests of detriment to the public interest as that Act had been interpreted as requiring. Yet the economic investigation which the appellant would have us require is of the same broad scope as adumbrated with reference to unreasonable restraints of trade in Chicago Board of Trade $v$. United States. . . To insist upon such an investigation would be to stultify the force of Congress' declaration that requirements contracts are to be prohibited wherever their effect 'may be' to substantially lessen competition."

In still another way was this implied in Justice Brennan's opinion: even though a great amount of evidence was adduced on all phases of the inter-relationship between du Pont and General Motors, the Court was satisfied with a showing that the requisite anticompetitive effect might appear in only one line of their dealings.

73. Voicing approval of this rule, the Attorney General's Committee reported as follows: "Sometimes, the market foreclosed may be so large as to support the necessary inference of substantially lessening of competitive opportunity. In others, different market factors may be equally significant in determining whether $\$ 7$ has been transgressed. In no merger case-horizontal, vertical or conglomerate-can a "quantitative substantiality' rule substitute for the market tests section 7 prescribes." REPORT, at 122. And see id. at 142. A minority indicated that they believed that the Standard Stations precedent was stronger than the quoted passage would indicate. Id. at 122 n.25.

74. For another view that the words of the act forbade a quantitative substantiality test, see Handler. Quantitative Substantiality and the Celler-Kefauver Act$A$ Look at the Record, 7 Mercer L. Rev. 279 (1956). Contra, Celler, Corporate Mergers and Antitrust Laws, 7 MERCER L. REv. 267 (1956), although a case-by-case approach would be satisfactory in cases involving small companies. Id. at 276.

For still a third view on the subject, see Bowman, Incipiency, Mergers and the Size Question: Section 7 of the Clayton Act, 1 ANTrTrust BuLl. 533 (1956). "If ... the courts interpret 'may tend' as not confined to exactly what the merger under review will do but rather to what is likely to happen if other members are allowed to do the same, then a great many mergers may be stopped ... where a considerably larger company exists. Such a determinant would be consistent with more rigorous standards than section 2 of the Sherman Act while avoiding the interpretation (as in the Standard Oil Co. of Cal. case) of section 3 of the Clayton Act." 
panies' percentage market shares, a decline in the number of mills, a lack of new entries and a movement in the direction of oligopoly in the urban markets.

The Commission made it clear that it was not applying a Sherman Act test. But since such a list of factors either bears a strong resemblance to a rule of reason approach or else is irrelevant, the Commission explained that the difference lay in the stringency of the burden of proof, it being somewhat less for a Clayton Act violation. Thus, at least one thing was clear: the Commission in its interpretation of section 7 had denied anything which might look like a "structure" test of violations and had instead settled on something which presumably is a performance or conduct test for "workable competition." 75

The question of structure versus performance as the proper test for section 7 had been faced in the Transamerica case $^{76}$ heavily relied upon in Pillsbury. The Transamerica Corporation was accused of violating the second paragraph of section 7 by acquiring the stock of banks representing forty-one per cent of the banking offices, over thirtynine per cent of the deposits and fifty per cent of the loan business in a five-state western area. The Board of Governors of the Federal Reserve System had concluded on the basis of the Standard Stations decision that these percentages were sufficient to show a violation. But the Court, citing among other things the International Shoe case, said that section 7 did not make an acquisition per se illegal merely on the showing of requisite percentages, but "requires a preliminary determination of the area of effective competition between the companies involved before the question of competition between them may be considered." 77 The Court then differentiated stock acquisitions from exclusive dealing arrangements, since the former do not necessarily foreclose any competition. ${ }^{78}$

75. Bowman, supra note 74, at 541. For the meaning of the terms as used here, see Stocking, The Rule of Reason, Workable Competition and Monopoly, 64 YALE L.J. 1107, 1110-12 (1955); Stocking, On the Concept of Workable Competition as an Antitrust Gitide, 2 ANTTTRUST ButL. 3 (1956). For a rather different view on the same distinction, see DIRLAM \& KaHN, FaIr Comperition 26 (1954). A list of relevant "workableness" factors of almost overwhelming proportions appears beginning on page 125 of the Report of the Attorney General's Committee. It is undoubtedly exhaustive. The factors listed under the fourth heading, "Long-range competitive consequences of the acquisition," sound as though they were cribbed from the enemy camp. Also see Lockhart \& Sacks, The Relevance of Economic Factors in Determining Whether Exclusive Arrangements Violate Section 3 of the Clayton Act, 65 Harv. L. REv. 913, 923-28 (1952), for another list of factors.

Incidentally, the Federal Trade Commission was not alone among government agencies in its approach to the merger question. See Attorney General Brownell's list of eleven items to be considered in merger cases in a speech delivered Sept. 30, 1954, CCH 1 TRADE REG. REP. $\pi$ 4205.25.

76. Transamerica Corp. v. Board of Governors, 206 F.2d 163 (3d Cir. 1953).

77. Id. at 167.

78. The case deals with the second paragraph of the old $\$ 7$ referring to the stock "of two or more companies," and "competition between such corporations," which the 
The principal thrust of Transamerica, perhaps overlooked in Pillsbury, was its determination that there existed no single market in which there might even be a possible tendency to monopoly. And it was certainly this aspect of the case which Justice Brennan had in mind when he quoted the following with expressed approval: "Accordingly in order to determine the existence of a tendency to monopoly in . . : any . . . line of business the area or areas of existing effective competition in which monopoly might be exercised must first be determined. . . "79 The court in Transamerica based its reversal on the finding by the Board that the business of the banks acquired was peculiarly local or intra-community with no competition between them. Since the court had already determined that this was the area of competition referred to by the relevant part of section 7 , this finding negated the existence of a violation. ${ }^{80}$ What Pillsbury assumed in Transamerica

court construes as settling the question of the relevant market. "The ban imposed by $\S 7$ in this regard is solely against stock acquisitions which may have the effect of substantially lessening competition between the companies acquired." Ibid.

The failure to see that Standard Stations does not negate inquiry into the relevant market question, but that the question is obviated in an exclusive dealership case, has clouded much of the discussion. See for example Lockhart \& Sacks, supra note 75, at 915. This same unprofitable analysis has occurred, it would seem, in much of the discussion of the International Shoe case. That case has been taken as applying a Sherman Act test. Lockhart \& Sacks, supra; Bowman, sipra note 74, at 535; REPORT, at 116 ; S. REP. No. 1775, 81st Cong., 2d sess. 4 (1950); H.R. REP. No. 1191, 81st Cong., 1st sess. 8 (1949); 96 CoNG. Rnc. 16502 (1950) ; see United States v. Republic Steel Corp., 11 F. Supp. 117 (N.D. Ohio 1935). But the case might well be looked at in another light. What the court did in fact was look for any market in which the proscribed effects might take place. Unless one could be found, it is difficult to see how even a per se violation can be talked about. This inquiry would seem to be a sine qua non for any kind of case, Sherman Act or Clayton, and, if no such market can be found, then no violation is conceivable.

The Court in International Shoe found no substantial competition between the two companies which could be restrained: And whatever tendency to restraint such a merger may have had was considerably ameliorated by the fact that the company acquired was in a failing condition with little likelihood of recovery. Much of the difficulty stems from the fact that the Court said it was applying a Sherman Act "rule of reason" test to see if competition was unduly restricted. International Shoe Co. v. FTC, 280 U.S. 291, 298 (1930). Viewed in this fashion then the "Sherman Act" test applied in International Shoe becomes no more than the search for a meaningful, relevant market, albeit on this point the Court may have taken a rather restrictive view of the incipiency notion. That no similar search is needed in a tying situation would seem to be almost axiomatic. Standard Oil Co. v. United States, 337 U.S. 293 (1949). And certainly the same is true when the market to be protected is defined by the statute. Transamerica Corp. v. Board of Governors, 206 F.2d 163 (3d Cir. 1953). But this type of inquiry is vastly different from the "performance" analysis demanded in the Pillsbury remand to determine competitive effect. To the extent that such a test was expressly applied in United States v. Republic Steel Corp., 11 F. Supp. 117 (N.D. Ohio 1935), that case could be considered to have misinterpreted the precedent. And see Aluminum Co. v. FTC, 284 Fed. 401 (3d Cir. 1922).

79. Transamerica Corp. v. Board of Governors, 206 F.2d 163, 169 (3d Cir. 1953), quoted in United States v. E. I. du Pont de Nemours \& Co., 353 U.S. 586, 593 (1957).

80. The Transamerica court said: "Evidence of mere size and participation in a substantial share of the line of business involved, the 'quantitative substantiality' theory relied on by the Board, is not enough." Transamerica Corp. v. Board of Governors, stupra note 79, at 170 . This language was used outside the context of the relevant market discussion by the Attorney General's Committee to conclude that no per se or market structure test was intended by $\S 7$. REPORT, at 119 . Several members disagreed. Id. at 120 n.15. Presumably Justice Brennan gave full approval to the mar- 
to be a vote for a performance rather than a structure test really turns out to be a discussion of the relevant market problem, but in a rather specialized form.

But the relevant market question in a horizontal merger situation is a different order of inquiry than that in a vertical merger. ${ }^{81}$ Really the only question (other than a quantitative one) is the one dealt with in Cellophane and International Shoe: how different are the commodities involved in terms of character and use, availability and price? Perhaps it is too restrictive to say the answer turns only on "patterns of trade which are followed in practice." 82 But difficult though the answer may be to discover, the proper question is not difficult to formulate or understand. And, of course, in these cases the level at which the relevant competition is to be found is understood. Furthermore one is not too disturbed by a severe burden of proof on the parties to a horizontal merger to justify its legality. Since by definition they were in competition, the merger a fortiori lessens that competition. ${ }^{83}$

A simple factual question is not posed, however, by the vertical mergers. In addition to the "commodity" question of horizontal mergers, there is the question of which level of competition, that of the acquired or acquiring company, is affected. And, of course, there is serious debate whether a vertical acquisition, without monopoly power at any horizontal level, can affect competition. The arguments have been well presented elsewhere, ${ }^{84}$ and no purpose will be served by repeating them here. The implications of the opposing arguments, however, are of some importance, for if it can be determined a priori that there

ket aspects of the case, but the implications drawn by the Attorney General's Committee from the "quantitative substantiality" language would seem implicitly to have been overruled by other portions of the du Pont decision in which no mention was made of the Transamerica opinion. See the strategic emphasis placed on the Standard Stations case. 353 U.S. at 586, 593.

81. For an interesting analysis of selection of relevant markets in this connection, see Turner, sipra note 59, at $315 \mathrm{n} .80$. The $d u$ Pont decision could have its greatest impact on the horizontal integration cases. A recent study of the twenty-eight cases instituted by the Justice Department and the Federal Trade Commission since 1950 indicates that all but two of the complaints are devoid of any reference to vertical integration, and those two contain allegations of horizontal merger as well. Markham, supra note 43.

82. United States v. United Shoe Mach. Corp., 110 F. Supp. 295, 303 (D. Mass. 1953), aff'd per curiam, 347 U.S. 521 (1954). For a workable process by which a court determines whether to define a market narrowly or broadly in a merger situation, see American Crystal Sugar Co. v. Cuban-American Sugar Co., 152 F. Supp. 387, 398 (S.D.N.Y. 1957).

83. If the parties could show real economies of scale in the industry, for instance, which the merger allowed to operate, this might be sufficient justification, although there should probably be a presumption in favor of natural rather than merger growth. To the extent that the acquired firm is or is about to go out of business, there is really no competition, and the acquisition is merely of bricks and mortar. This, of course, is very different from the test prescribed in Pillsbury.

84. Bork, supra note 38 . 
is no substantial anticompetitive effect to be expected from a vertical integration, then there is no need to proceed with the kind of analysis called for by Pillsbury.

Perhaps one point, not purely of an economic nature, should be noted about vertical acquisitions. One likely effect of acquiring a customer corporation is to reduce a competitor's choice of customers even though the industry may remain unquestionably competitive. ${ }^{85}$ And if enough such acquisitions take place, new entries into the industry can only be made as integrated units. The additional capital required may thereby decrease the number of individuals who will consider entering. ${ }^{80}$ For those who have preferred an economy composed of a large number of small units, regardless of economies of scale or integration, such a result is anathema.

The 1950 amendment to section 7 remains to be considered. It is clear that the one dramatic feature of that amendment was the inclusion of asset acquisitions, but other changes it purported to introduce we now know to have been the law all along. ${ }^{87}$ For instance, the amendment was to change the Sherman Act approach believed to have been introduced in International Shoe to either a per se rule, or perhaps merely to something requiring a lesser burden of proof than the Sherman Act. The amendment was also designed to make it clear that section 7 applied to vertical and conglomerate mergers as well as horizontal ones. And the amendment was further designed to insure that not merely the competition between the acquired and acquiring companies was to be protected but that in any line of commerce in any section of the country. The $d u$ Pont case indicates that none of these changes was really necessary.

85. Of course, it is not a necessary consequence of every total stock acquisition that the acquired company cease dealing with the acquiring company's competitors, but that is the logical result. Unless the acquisition is solely for investment, the management must contemplate some form of integration between the two companies, either for technological reasons or reasons of marketing economies. In either instance the result described will probably follow. Cf. Fargo Glass \& Paint Co. v. Globe Am. Corp., 201 F.2d 534 (7th Cir. 1953).

86. Bork, supra note 38 , takes the position that this is not anticompetitive. But see Rostow \& Sacks, Entry into the Oil Refining Business: Vertical Integration Reexamined, 61 YALE L.J. 856, 877 (1952).

87. There might be one other exception to this statement, however, in the case of certain vertical acquisitions. As we have seen, note 13 supra, the second alternative test in the old $\$ 7$ could be interpreted to comprehend only horizontal acquisitions. Thus vertical acquisitions would be illegal only if they tended to create a monopoly, while the restraint of competition test would apply to horizontal or vertical acquisitions. Under the amended $\$ 7$, either test clearly applies to either kind of acquisition. But Justice Brennan's interpretation of monopoly is so broad that it would seem to cover any vertical acquisition situation which might be seriously questioned. For that matter, following the "foreclosure" implications of the opinion, it is difficult really to see any difference between a restraint of competition and a tendency to monopoly. See note 16 supra. 


\section{IMPLICATIONS AND CONCLUSIONS}

Possibly many famous Sherman Act cases could never have arisen in the fashion we know if the Government had had an effective antimerger statute at the time. ${ }^{88}$ The Sherman Act and the rule of reason have had their days in court. The battle rages over how effectively they have done their job, just as the battle rages over what the nature of the monopoly problem really is. Many a baseball team has shown new life by moving to a new stadium, and perhaps the antitrust laws were growing a bit moribund in the old arena. A new departure stimulates thought and introspection. But whatever the analysis, for some time to come much of the attention of law enforcement agencies and the antitrust bar must be directed to the Clayton Act and the $d u$ Pont decision.

This would not have followed if the Government had had its way, since then a new violation, or a variation of an old one, would have been added to the Sherman Act list. ${ }^{89}$ The Government proceeded on the theory that abuses were involved, bringing the case within the Paramount rule and distinguishing it from Columbia Steel. If such abuses had been found, however, in the form of coerced trading with the parent company, certainly a heavy cloud would have been thrown on Columbia Steel, where the Court found no abuses though assets were purchased by a wholly owned subsidiary and it was recognized that the subsidiary would buy only from its parent.

In proceeding in the $d u$ Pont case the Government was possibly looking for a rule which would affect pre-1950 asset acquisitions, and it may have been that the Justice Department did not believe that the Clayton Act, with its history and tradition of economic fact analysis, was competent to handle the existing merger problem in safe time. ${ }^{80}$ But it cannot be overlooked that the Sherman Act carries with it criminal sanctions, injunction power and trial advantages not found in the Clayton Act; and, possibly most important, many people simply feel

88. In addition to the pointedly vertical integration cases like Yellow Cab, Paramount and Columbia Steel, such a list might include United States v. United States Steel Corp., 251 U.S. 417 (1920) ; Standard Oil Co. v. United States, 221 U.S. 1 (1911) ; United States v. American Tobacco Co., 221 U.S. 106 (1911); United States v. Aluminum Co., 148 F.2d 416 (2d Cir. 1945).

89. That this would seem to have been a new rule is interestingly attested to by the charge to the jury of the district court judge in United States v. National City Lines, 186 F.2d 562 (7th Cir. 1951). The passage appears in id. Transcript of Record, p. 1176, cited in Comment, Vertical Forestalling Under the Antitrust Lazes, 19 U.' CHI. L. REv. 583, 603 (1952) : "It is not unlawful to make a requirements contract, and it is not unlawful to make an investment of risk capital in the stock of a customer or a potential customer for the purpose of producing a new market."

90. The results to date in the Pillsbury case would certainly seem to bear this out. See pp. 401-06 sipra. 
that the Sherman Act presents the more desirable approach to antitrust enforcement.

As interpreted by the Court, the Clayton Act had several positive "advantages" over the Sherman Act. In the first place, the Court had an earlier opportunity than would otherwise have been possible to clarify the meaning not only of the old but also the new section 7 . Whatever the Court decided in $d u$ Pont would have decided relevance in cases of horizontal acquisitions or mergers under section 7-a much more important area ${ }^{91}$ - since these are outlawed by the same language. This is certainly not true under the Sherman Act, as there the defense must be available that, apart from horizontal effect, a vertical merger, in and of itself, has no adverse economic effect, ${ }^{92}$ or that there might be justifiable technological advantages. ${ }^{93}$ The possibility of defenses not yet fully developed under the Sherman Act cannot be overlooked. But quite the contrary may be true in Clayton Act cases. ${ }^{94}$

There remains, however, the actual problem raised by Columbia Steel, for an acquisition of assets prior to 1950 is still safely insulated from the bite of section 7. Paradoxically the $d u$ Pont case may have had the effect of strengthening the Sherman Act in this regard. In Columbia Steel the Court said that the public policy announced by section 7 of the Clayton Act was to be taken into consideration in determining whether acquisitions of assets of Consolidated by United States Steel with the same economic results as a purchase of the stock violated the prohibitions of the Sherman Act against unreasonable restraints. ${ }^{95}$ There has evidently been a change in what the public policy of section 7 was thought to be, and perhaps now the market test of section 7 applies to the Sherman Act as well. If so, the Sherman Act may still have some real vitality in the merger area.

But the last suggestion is somewhat farfetched, and the wind is far more likely to blow in the other direction. The history of the Sherman Act probably tells us more about what we may expect from the Clayton Act than vice versa. And just as $Y$ ellow $C a b$ was followed by Paramount and ultimately by Columbia Steel, so $d u$ Pont could be supra.

91. And it is in this area that the section will have its greatest use. See note 80

92. United States v. Columbia Steel Co., 334 U.S. 495, 526 (1948) ; see Bork, supra note 38; Comment, Vertical Forestalling Under the Antitrust Laws, 19 U. CHI. L. Rev. 583 (1952). But see Markham, supra note 43; Adelman, Integration and the Antitrust Laws, 63 Harv. L. Rev. 27 (1949); Kahn, supra note 61.

93. United States v. United Shoe Mach. Corp., 110 F. Supp. 295, 342 (D. Mass. 1953), aff'd per curian, 347 U.S. 521 (1954); United States v. Aluminum Co., 148 F.2d 416, 430 (2d Cir. 1945).

94. See Justice Brennan's explicit treatment of the "solely for investment" defense, 353 U.S. at 597, and of the specific intent point. Id. at 607 .

95. United States v. Columbia Steel Co., 334 U.S. 495, 507 n.7 (1948). 
followed by blow-softening decisions. Actually the analogy is not completely apocryphal. The Court's emphasis was on proof of "reasonable probability," a discussion which strongly suggested the "power" and "purpose" terms of Sherman Act fame. ${ }^{96}$ The "power" phase of the proof was in terms of the increases in General Motors' purchases from du Pont after the acquisition and the control which the bloc of shares seemed to carry. The "purpose" phase of the proof was in terms of statements of intent to get a larger share of General Motors' purchases and evidence of du Pont's need for new markets. Power and purpose could become necessary ends in themselves. From there, of course, it is but a small step to require some abuse to flow from the acquisition.

But there are, as we have seen, some rather obvious faults in the $d u$ Pont analysis, and it is not unreasonable to expect that in time the courts will recognize them and supply correctives. One may not freely predict a reversal, but there are many areas in which distinctions could meaningfully be made in the future, and perhaps so many that in time little would be left of the decision.

As a matter of stating a rule, it would seem apparent that no future court can be expected to say that vertical acquisitions were not intended to be included within section $7 .{ }^{97}$ But this will not stop any subsequent court from examining the relevant economic facts to determine whether or not a particular acquisition has the proscribed effect.

This leads naturally to the question of probability. As we have seen, the Court was actually asking whether the acquisition in question would probably have the same effect as a total acquisition, rather than asking about the probability of certain economic consequences. If this is recognized in the future, then it is not unlikely that the rule of $d u$ Pont will be limited to partial acquisitions of stock. In total acquisitions, the question of probabilities cannot involve control, and unless the courts are willing to follow completely all the implications of Standard Stations, they will have to look for probabilities of economic consequences. An analysis not attempted at all in $d u$ Pont will be necessary. There would be leeway to avoid many of $d u$ Pont's implications, for instance that any total acquisition necessarily eliminates competition. This would give an opportunity to reappraise the definition of the relevant market used in $d u$ Pont, for relevancy would now go to a different point, namely the level of industry affected rather than the particular product in question. Of course, the relevant market rule

96. See Rostow, Monopoly Under the Sherman Act: Power or Purpose?, 43 ILI. L. REV. 745 (1949).

97. But for what could be an analogous switch in position, cf. Ried v. Covert, 351 U.S. 487 (1956), withdrazm, 354 U.S. 1 (1957). 
of $d u$ Pont should be relatively easy to change by a distinction on the facts of the case. For there is nothing shown in the Court's recitation to indicate just how the relevant line of commerce is delineated.

It would be unfortunate, however, if $d u$ Pont were exchanged in toto for the cross-elasticity of demand or substitutable commodity approach of Cellophane. What may be hoped is that the courts will now determine which of those two rules is appropriate for any given case and not become confused by mere surface similarities such as which statute is being applied.

The horizontal merger cases present a good example of how this determination might be made. ${ }^{98}$ A horizontal merger does not have much to recommend it as a general rule, but there is the problem of determining when an acquisition is in fact horizontal, or, stated differently, when there is a relevant market affected. If the market is narrowly drawn, as in $d u$ Pont, we might find a court approving the merger of a company manufacturing cellophane and some other type of flexible wrap. This could restrain a substantial amount of competition, at least for the many buyers for whom these products were the only reasonable alternatives. The Cellophane rule would have real meaning for this type of merger. No court faced with such a situation should mechanically apply the narrow market test of $d u$ Pont simply because that, unlike Cellophane, was a section 7 case. And the $d u$ Pont rule needs to be retained for just those cases like Cellophane where substitutability is found but for any reason some buyers cannot substitute. ${ }^{99}$

Although the Government is fairly busy prosecuting post-1950 mergers, it may now take a long look back if it so desires. The potentiality of the restraint of competition or tendency to monopoly is to be viewed as of the time of suit and not as of the time of the original acquisition. Any acquisition of stock which took place after the passage of the Clayton Act in 1914 has a cloud over it, although there would seem to be no problem under the older section 7 if after the stock acquisition the assets of the subsidiary were also acquired. ${ }^{100}$ The uneasy

98. Incidentally it may be that less stock will be sufficient for a horizontal violation than for a vertical one. In the vertical case the holding has to be large enough to make it reasonably probable that the acquiring company could coerce the purchase of its goods. In the horizontal case, however, enough stock to secure one member of the board of directors might conceivably be sufficient, since the companies are then in a position to facilitate a restraint of competition between themselves. See Hamilton Watch Co. v. Benrus Watch Co., 114 F. Supp. 307, 316-17 (D. Conn.), aff'd, 206 F.2d 738 (2d Cir. 1953). But the existence of $\$ 8$ of the Clayton Act dealing expressly with the problem of interlocking directorships would seem to make an extension of the notion to the stock acquisition area unlikely.

99. This seems contradictory, but as long as results like that in Cellophane are possible-even with an acceptable statement of the analysis to be made-the courts need other standards which can be invoked to reach more satisfactory results.

100. Thatcher Mfg. Co. v. FTC, 272 U.S. 554 (1926). There was no indication in the du Pont case that this old rule approving a stock acquisition followed by an 
feeling engendered by this rule has been mentioned, and the uneasiness is aggravated by the unevenness with which the rule operates in the whole merger field. It is only in the cases in which the stock was acquired and held by a parent company that the time rule is going to have much relevance to pre-1950 acquisitions ${ }^{101}$ and probably then only if more than fifty per cent of the stock was acquired. ${ }^{102}$

Presumably the pending merger complaints are all cases brought "at or near" the time of acquisition. The $d u$ Pont case could well be the last of its kind for many years to come, since it represents a relatively rare situation. But as more time elapses the rule may have increased relevance and use, and, for what difference it could make, ${ }^{103}$ the time rule apparently applies not only to section 7 but to the other sections of the act using the "may tend" language.

As we have seen, ${ }^{104}$ it is precisely in the total acquisition case that the appropriate time rule announced in $d u$ Pont appears most unfair, since by and large all economic probabilities for which the parties might reasonably be held responsible are evident at the time of the acquisition. These situations, unlike that in $d u$ Pont, represent true economic mergers, the subject of much concern and discussion today. Some legislation on the subject appears imminent, and perhaps the opportunity should be taken to correct the appropriate time rule of $d u$ Pont as applied to mergers.

Bills recently introduced in Congress ${ }^{105}$ require notifying the Federal Trade Commission or the Justice Department of the details of any merger over a certain size and provide penalties to enforce reporting. If the Justice Department and the Federal Trade Commission were

asset acquisition before suit had been overruled. Since the time of suit is the appropriate time to look for the probability of an effect on competition or tendency to monopoly, it would seem that the Thatcher rule is still controlling for a suit under the earlier version of $\$ 7$.

101. That the Government has no plans for a mass dissolution of American industry has already been authoritatively announced. See report of speech by member of the Antitrust Division. The statement also alluded to the difficulties of adequate remedies in asset acquisition cases. Time, July 29, 1957, p. 72. See United States v. United Shoe Mach. Corp., 110 F. Supp. 295, 348 (D. Mass. 1953), aff'd per curiam, 347 U.S. 521 (1954). For the difficulties encountered in stock divestments, see Skilton, Cars for Sale: Some Comments on the Wholesale Financing of Automobiles, 1957 WIs. L. REV. 352, 365; Kessler, Automobile Dealer Franchises: Vertical Integration by Contract, 66 YALE L.J. 1135, 1162 n.183 (1957). On the other hand, for an indication that the du Pont decision will allow the Government to move fast, see report of the motion for summary judgment in the Bethlehem case. New York Times, June 14, 1957, p. 35, col. 2.

102. See analysis at pp. 393-94 supra.

103. As we have seen, except in the case of a partial stock acquisition, and barring a change in the share of the market affected, the probabilities of economic consequences are never greater than at the time this acquisition occurs. Ibid.

104. See pp. 393-94 supra.

105. For example, see S. REP. No. 198, 85th Cong., 1st Sess. (1957); H.R. REP. No. 7698, 85th Cong., 1st Sess. (1957). 
given the power in the first instance to pass on the validity of a merger under section 7, that is on the probability of its anticompetitive effects, no enforcement provisions would be required. The determination would work in the same manner as the doctrine of res judicata, and the decision of the Justice Department, the Federal Trade Commission or any court to which an appeal was made would be final. By reporting the merger, the parties to it could avoid the danger of a later, surprising suit subjecting them to the full force and effect of the $d u$ Pont decision. Nor should businesmen be allowed to pick the time at which they would attempt to gain approval. If the acquisition were not reported within, say, one year, then the scheme would no longer be available to the parties. It is probably safe to presume that most businessmen would want the practical advantage of a determination. 